\title{
ERRATUM
}

\section{Do we have to kill the last CML cell?}

\author{
DM Ross ${ }^{1,2}$, TP Hughes ${ }^{1}$ and JV Melo ${ }^{1}$ \\ ${ }^{1}$ Department of Haematology, SA Pathology Centre for Cancer Biology, University of Adelaide, Adelaide, South Australia, \\ Australia and ${ }^{2}$ Department of Haematology and Genetic Pathology, School of Medicine, Flinders University, Adelaide, \\ South Australia, Australia
}

Leukemia (2011) 25, 386; doi:10.1038/leu.2010.250

Correction to: Leukemia advance online publication, 16 September 2010; doi:10.1038/leukemia.2010.197

Since the publication of this article, the authors have noticed several errors that appeared in the online version of their paper. These errors have now been rectified, and the correct article appears in this issue. The html and online pdf versions have also been rectified, and now carry the correct paper.

The corrections are listed below:

The author list was incorrect. Both TP Hughes's and JV Melo's authorship have been changed to affiliation 1. The correct author list and affiliations are shown above.

The word 'leukaemic' has been changed to 'leukaemia' throughout the article.

References 40, 57, 61, 62 and 64 were incorrect, and have been substituted with the following:

40 Radich JP, Gehly G, Gooley T, Bryant E, Clift RA, Collins S et al. Polymerase chain reaction detection of the $\mathrm{BCR}-\mathrm{ABL}$ fusion transcript after allogeneic marrow transplantation for chronic myeloid leukemia: results and implications in 346 patients. Blood 1995; 85: 2632-2638.
57 Rezvani K, Grube M, Brenchley JM, Sconocchia G, Fujiwara $\mathrm{H}$, Price DA et al. Functional leukemia-associated antigen-specific memory CD8 $+\mathrm{T}$ cells exist in healthy individuals and in patients with chronic myelogenous leukemia before and after stem cell transplantation. Blood 2003; 102: 2892-2900.

61 Bocchia M, Gentili S, Abruzzese E, Fanelli A, luliano F, Tabilio A et al. Effect of a p210 multipeptide vaccine associated with imatinib or interferon in patients with chronic myeloid leukaemia and persistent residual disease: a multicentre observational trial. Lancet 2005; 365: 657-662.

62 DeAngelo DJ, Hochberg EP, Alyea EP, Longtine J, Lee S, Galinsky I et al. Extended follow-up of patients treated with imatinib mesylate (gleevec) for chronic myelogenous leukemia relapse after allogeneic transplantation: durable cytogenetic remission and conversion to complete donor chimerism without graft-versus-host disease. Clin Cancer Res 2004; 10: 5065-5071.

64 Butt NM, Rojas JM, Wang L, Christmas SE, Abu-Eisha HM, Clark RE. Circulating bcr-abl-specific CD8 + T cells in chronic myeloid leukemia patients and healthy subjects. Haematologica 2005; 90: 1315-1323.

The authors and the publishers apologize for any inconvenience caused. 